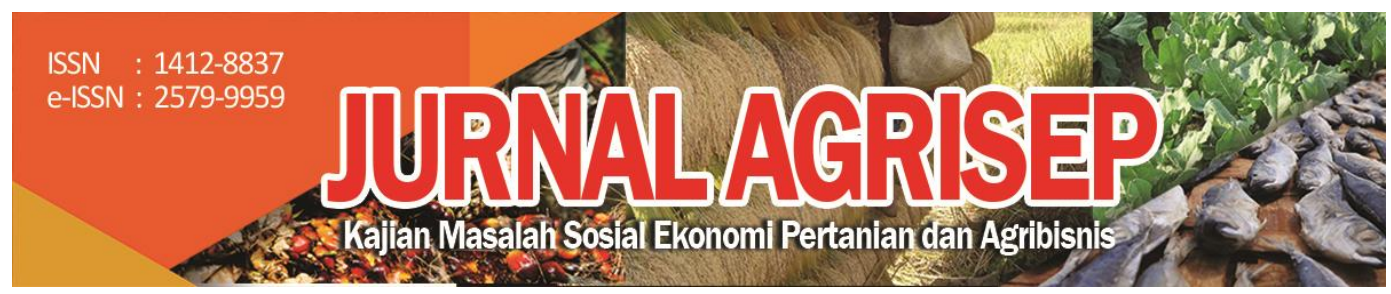

DOI: 10.31186/jagrisep.19.1.207-218

\title{
STRATEGI PENGEMBANGAN USAHATANI JAGUNG PADA LAHAN KERING DI KABUPATEN WONOSOBO
}

\author{
Development Strategy of Maize Farming on Dry Land \\ In Wonosobo Regency
}

\author{
Wiwit Rahayu1) $\square$, Umi Barokah2), Rhina Uchyani Fajarningsih'3) \\ 1),2), 3) Program Studi Agribisnis Fakultas Pertanian Universitas Sebelas Maret \\ Email: wiwitrahayu@staff.un
}

\begin{abstract}
Wonosobo Regency is one of the maize producing districts in Central Java. The harvested area and maize production in Wonosobo Regency from 2015-2018 tended to decrease. Maize in Wonosobo is widely cultivated on dry land in the highlands. This study aims to analyze costs, income, efficiency and formulate strategies alternative for developing maize farming on dry land in Wonosobo Regency. The data used are primary data obtained through interviews with 45 sample farmers and Focus Group Discussions with key informants consisting of farmers, agriculture services, BAPPEDA, plantation and forestry services, maize traders, and consumers. Data analysis was performed by analysis of costs, income, and farm efficiency and SWOT analysis. The results showed that in I and II growing seasons, the cost of maize farming was IDR 3,936,072.00, revenue IDR 9,905,412.00, and income was IDR 5,969,340.00. $R / C$ value of 2.51 shows that maize farming in Wonosobo Regency is efficient. Strategies alternative for developing maize farming are: (1) Increasing the quantity and quality of maize commodities by optimally utilizing government policy support, (2) Increasing production through expansion of maize planting land, (3) Expanding maize marketing, (4) Increasing farmer capital, (5) Development of location-specific seeds, and (6) Increasing the role of farmer groups in facing competition.
\end{abstract}

Keywords: Corn farming, Dry land, Development strategy, Wonosobo

\section{ABSTRAK}

Kabupaten Wonosobo merupakan salah satu kabupaten penghasil jagung di Jawa Tengah. Luas panen dan produksi jagung di Kabupaten Wonosobo dari 
tahun 2015-2018 cenderung menurun. Jagung di Wonosobo banyak dibudidayakan pada lahan kering di dataran tinggi. Penelitian ini bertujuan untuk menganalisis biaya, pendapatan, efisiensi dan merumuskan alternatif strategi pengembangan usahatani jagung pada lahan kering di Kabupaten Wonosobo. Data yang digunakan adalah data primer yang diperoleh melalui wawancara kepada 45 petani sampel dan Focus Group Discussion dengan key informan yang terdiri atas petani, dinas pertanian, BAPPEDA, dinas perkebunan dan kehutanan, pedagang jagung,dan konsumen. Analisis data dilakukan dengan analisis biaya, pendapatan, dan efisiensi usahatani serta analisis SWOT. Hasil penelitian menunjukkan bahwa usahatani jagung pada lahan kering di Kabupaten Wonosobo dikakukan dengan rata-rata luas lahan 0,45 ha dan selama MT I dan MT II mengeluarkan biaya sebesar Rp 3.936.072,00, memperoreh penerimaan sebesar $\mathrm{Rp} 9.905 .412,00$, sehingga pendapatan sebesar $\mathrm{Rp}$ 5.969.340,00. Nilai R/C sebesar 2,51 menunjukkan bahwa usahatani jagung di Kabupaten Wonosobo efisien. Alternatif strategi pengembangan usahatani jagung yang dirumuskan adalah (1) Peningkatan kuantitas dan kualitas komoditas jagung dengan memanfaatkan secara optimal dukungan kebijakan pemerintah , (2) Peningkatan produksi melalui perluasan lahan penanaman jagung, (3) Perluasan pemasaran jagung, (4) Peningkatan modal petani, (5) Pengembangan benih spesifik lokasi ( tahan hama dan kekeringan ), dan (6) Peningkatan peran kelompok tani dalam menghadapi persaingan.

Kata kunci: Usahatani jagung, Lahan kering, Strategi pengembangan, Wonosobo

\section{PENDAHULUAN}

Tanaman pangan merupakan komoditas penting yang dibutuhkan masyarakat dalam kehidupan sehari-hari. Jagung merupakan salah satu komoditas tanaman pangan utama sebagai sumber karbohidrat yang berperan dalam menunjang ketahanan pangan dan kecukupan pasokan pakan ternak. Peluang pengembangan usahatani jagung masih terbuka karena selain berkembangnya industri pangan maupun pakan berbahan baku jagung, masih terdapat penduduk yang mengonsumsi jagung sebagai makanan pokok. Salah satu daerah di Jawa Tengah yang sebagian penduduknya masih mengonsumsi jagung sebagai makanan pokok adalah Kabupaten Wonosobo.

Kabupaten Wonosobo merupakan salah satu kabupaten penghasil jagung di Jawa Tengah. Jagung di Kabupaten Wonosobo banyak dibudidayakan di lahan kering. Sebagian besar lahan pertanian di Kabupaten Wonosobo adalah lahan kering yaitu tegalan seluas $42.000 \mathrm{Ha}$, sedangkan sawahnya seluas 17.144 Ha. Tegalan di Kabupaten Wonosobo berada di dataran tinggi sehingga memiliki karakteristik usahatani jagung yang berbeda dengan tegalan di dataran rendah. 
Usahatani jagung di lahan kering menghadapi kendala antara lain masalah unsur hara yang kurang dan kelangkaan air. Rukmana (1995) mengatakan lahan kering adalah sebidang tanah yang dapat digunakan untuk usaha pertanian dengan menggunakan atau memanfaatkan air secara terbatas dan biasanya tergantung dari air hujan Setiawan (2007) menyatakan bahwa terdapat tiga permasalahan utama usahatani lahan kering, yaitu: erosi (terutama bila lahan miring dan tidak tertutup vegetasi secara rapat), kesuburan tanah (umumnya rendah sebagai akibat dari proses erosi yang berlanjut), dan ketersediaan air (sangat terbatas karena tergantung dari curah hujan). Ciri lainnya adalah makin menurunnya produktifitas lahan, macam spesies tanaman yang ditanam, rendah adopsi teknologi maju, serta terbatasnya ketersediaan modal dan infrastruktur yang tidak sebaik di daerah sawah.

Usahatani jagung pada lahan kering juga menghadapi masalah penurunan luas tanam maupun luas panen karena bersaing dengan tanaman lain yang dianggap lebih menguntungkan, padahal lahan merupakan faktor yang berpengaruh dalam produksi jagung. Pada tahun 2015 luas tanam jagung di Wonosobo adalah 26.888 Ha dengan produksi sebanyak 101.123 kuintal menduduki posisi nomor 10 di Jawa Tengah dan tertinggi di eks karisidenan Kedu (BPS Jawa Tengah, 2016). Luas panen dan produksi jagung di Kabupaten Wonosobo cenderung menurun yaitu pada tahun 2017 luas panen menjadi 21.818 Ha dan produksi sebesar 86.363 kuintal (BPS Jawa Tengah, 2018) dan tahun 2018 menurun lagi menjadi 19.838 Ha dan 71.845 kuintal (BPS Jawa Tengah, 2019).

Selain penurunan produksi dan luas lahan, produktivitas usahatani jagung di Kabupaten Wonosobo juga tergolong rendah dibandingkan Kabupaten lain di Jawa Tengah. Pada tahun 2015 dan 2017 produktivitas usahatani jagung di Kabupaten Wonosobo sebesar 37,61 kuintal/ha dan 39,58 kuintal/ha menduduki posisi keempat terendah diantara 36 kabupaten dan kota di Jawa Tengah (BPS Jawa Tengah, 2016 dan 2018). Pada tahun 2018 produktivitasnya menurun menjadi 36,22 kuintal/ha dan menduduki posisi terendah diantara kabupaten dan kota di Jawa Tengah (BPS Jawa Tengah, 2019).

Berdasarkan latar belakang yang telah diuraikan, penelitian ini bertujuan untuk menganalisis biaya, pendapatan, dan efisiensi usahatani jagung lahan kering di Kabupaten Wonosobo serta merumuskan alternatif strategi pengembangannya.

\section{METODE PENELITIAN}

Penelitian dilakukan di Kabupaten Wonosobo yaitu di Kecamatan Mojotengah dan Kecamatan Kalikajar dengan mengambil sampel sebanyak 45 petani jagung untuk analisis usahatani. Sedangkan untuk perumusan alternatif strategi pengembangan usahatani jagung digunakan key informan dari petani, 
dinas pertanian, BAPPEDA, dinas perkebunan dan kehutanan, pedagang jagung,dan konsumen.

Data yang digunakan adalah data primer yang diperoleh melalui wawancara kepada petani dan Focus Group Discussion dengan key informan. Analisis data yang dilakukan meliputi analisis biaya, penerimaan, pendapatan dan efisiensi usahatani jagung. Analisis biaya dilakukan dengan menghitung biaya mengusahakan (biaya alat-alat-alat luar ditambah biaya tenaga kerja dalam keluarga). Penerimaan usaha tani jagung dihitung dengan mengalikan jumlah produksi jagung dengan harganya. Pendapatan usahatani jagung dihitung dengan mengurangi penerimaan dengan biaya usahatani jagung. Efisiensi usahatani jagung diukur dengan nilai R/C yang merupakan perbandingan antara penerimaan dan biaya (Suratiyah, 2008). Analisis data untuk merumuskan alternatif strategi pengembangan usahatani jagung dilakukan dengan analisis SWOT (Rangkuti, 2001).

\section{HASIL DAN PEMBAHASAN}

\section{Karakteristik Usahatani Jagung pada Lahan Kering di Kabupaten Wonosobo}

Usahatani Jagung di Kabupaten Wonosobo dilaksanakan dua kali dalam setahun dengan rata-rata luas lahan pada musim tanam (MT) I sebesar 0,45 $\mathrm{Ha}$ dan pada musimtanam (MT) II sebesar 0,4 ha. Sistem tanam yang diterapkan oleh petani jagung di Kabupaten Wonosobo adalah system tanam tumpang sari antara jagung dengan cabai dan jagung dengan sayuran lain. Hasil ini menunjukkan bahwa di tegalan pada umumnya jagung ditanamsecara tumpang sari dengan tanaman lain.

Jenis jagung yang ditanam di Kabupaten Wonosobo sebagian besar adalah jagung lokal varietas Arjuna. Benih yang digunakan oleh petani berasal dari hasil panen sebelumnya. Jagung lokal lebih dipilih oleh petani karena memiliki karakteristik lebih tinggi dan lebih kuat sehingga lebih tahan terhadap angin yang sering muncul di daerah pegunungan/dataran tinggi. Selain itu jagung lokal digunakan sebagai makanan pokok sehari-hari penduduk daerah pegunungan. Jagung lokal kering dapat disimpan hingga satu tahun, sehingga dapat dijadikan cadangan pangan oleh petani.

\section{Biaya Usahatani Jagung pada Lahan Kering di Kabupaten Wonosobo}

Biaya usahatani jagung adalah pengeluaran-pengeluaran yang dilakukan oleh petani dalam usahatani jagung meliputi biaya sarana produksi (benih, pupuk, pestisida) tenaga kerja, transportasi, penyusutan alat, pajak tanah, dan sewa mesin pemipil. Biaya usahatani jagung pada lahan kering di Kabupaten Wonosobo pada MT I $(0,45$ ha) dan MT II $(0,40)$ disajikan pada Tabel 1. 
Tabel 1. Biaya Usahatani Jagung pada Lahan Kering di Kabupaten Wonosobo

\begin{tabular}{|c|c|c|c|c|c|}
\hline \multirow{2}{*}{\multicolumn{2}{|c|}{ Biaya }} & \multicolumn{2}{|c|}{ Nilai $(\mathrm{Rp})$} & \multirow[t]{2}{*}{ Total (Rp) } & \multirow[t]{2}{*}{ Persentase $(\%)$} \\
\hline & & MT I & MT II & & \\
\hline Benih & & $68.755,00$ & $45.111,00$ & 113.866 & 2,89 \\
\hline Pupuk & & $858.175,00$ & $446.400,00$ & 1.304 .575 & 33,14 \\
\hline Pestisid & & $15.267,00$ & $15.200,00$ & $30.467,00$ & 0,77 \\
\hline $\begin{array}{l}\text { Tenaga } \\
\text { Luar }\end{array}$ & kerja & $586.311,00$ & $247.311,00$ & $833.622,00$ & 21,18 \\
\hline $\begin{array}{l}\text { Sewa } \\
\text { Pemipil }\end{array}$ & Mesin & $86.158,00$ & $83.500,00$ & $169.658,00$ & 4,31 \\
\hline Pajak T & nah & $21.392,00$ & $21.392,00$ & $42.784,00$ & 1,09 \\
\hline Penyus & & $27.383,00$ & $27.383,00$ & $54.766,00$ & 1,39 \\
\hline Transop & tasi & $74.222,00$ & $70.100,00$ & $144.322,00$ & 3,67 \\
\hline $\begin{array}{l}\text { Tenaga } \\
\text { Keluarg }\end{array}$ & Kerja & $717.656,00$ & $524.356,00$ & $1.242 .012,00$ & 31,55 \\
\hline Total & & 2.455 .319 & $1.480 .773,00$ & $3.936 .072,00$ & 100,00 \\
\hline
\end{tabular}

Sumber: Analisis Data Primer 2017

Tabel 1. menunjukkan bahwa biaya terbesar adalah biaya tenaga kerja yang meliputi tenaga kerja luar $(21,18 \%)$ dan tenaga kerja dalam keluarga $(31,55 \%)$. Hal ini menunjukkan bahwa usahatani jagung pada lahan kering di Kabupaten Wonosono masih padat tenaga kerja dan peran tenaga kerja dalam keluarga masih besar.

Biaya pupuk merupakan biaya terbesar kedua setelah tenaga kerja dengan kontribusi sebesar $33,14 \%$ terhadap total biaya. Pupuk yang paling banyak digunakan dan biayanya paling besar adalah pupuk urea. Pupuk merupakan salah satu faktor penting yang mempengaruhi produksi jagung. Hasil penelitian Mewalili dan Rouf (2014) menunjukkan bahwa variabel pupuk berpengaruh nyata terhadap produksi jagung dengan nilai koefisien regresi sebesar 0,875 berarti bahwa penambahan pupuk sebesar $1 \%$ akan meningkatkan produksi jagung sebesar $0,875 \%$ dengan asumsi bahwa faktor lain dianggap konstan.

Biaya benih dan biaya pestisida tidak mendominasi biaya usahatani jagung pada lahan kering di Kabupaten Wonosobo. Biaya benih sebesar Rp $113.866,00$ atau $2,89 \%$. Hal ini disebabkan sebagian besar benih yang digunakan petani adalah benih lokal sehingga harganya lebih murah daripada benih hibrida dengan harga berkisar Rp 5000,00 - Rp 6.000,00/kilogram. Benih yang digunakan oleh petani sebagian besar juga dari hasil panen sebelumnya tetapi dalam penelitian ini dihitung sebagai biaya dengan menggunakan harga yang berlaku apabila benih tersebut berasal dari pembelian.

Biaya pestisida merupakan biaya terkecil yaitu sebesar Rp 30.467,00 atau $0,77 \%$ dari total biaya usahatani jagung. Petani tidak banyak menggunakan 
pestisida karena tidak banyak terjadi serangan hama. Pestisida yang utama digunakan adalah fungisida untuk mengatasi jamur penyebab penyakit bulai.

\section{Pendapatan dan Efisiensi Usahatani Jagung pada Lahan Kering di Kabupaten Wonosobo}

Rata-rata jumlah produksi, harga, penerimaan, total biaya, pendapatan, dan efisiensi usahatani jagung pada lahan kering di Kabupaten Wonosobo disajikan pada Tabel 2.

Table 2. menunjukkan bahwa jumlah produksi jagung pada musim tanam pertama lebih banyak yaitu sebesar 1.605,50 kilogram daripada musim tanam kedua sebesar 549 kilogram, namun harga pada musim tanam kedua lebih besar yaitu sebesar Rp 4.798,00/kilogram. Total penerimaan selama satu tahun sebesar Rp 9.905.412,00 dan total biaya sebesar Rp 3.936.072,00 sehingga diperoleh pendapatan sebesar Rp 5.969.340,00. Hasil ini menunjukkan usahatani jagung pada lahan kering di Kabupaten Wonosobo masih bisa memberikan pendapatan kepada petani. Pendapatan ini pada kenyataannya bisa lebih besar karena biaya benih dan tenaga kerja keluarga pada analisis ini dihitung sebagai biaya padahal petani menggunakan benih dari produksi sebelumnya dan tenaga kerja dalam keluarga tidak diupah.

Tabel 2.Rata-Rata Jumlah Produksi, Harga, Penerimaan, Total Biaya, Pendapatan, Dan Efisiensi Usahatani Jagung Pada Lahan Kering Di Kabupaten Wonosobo

\begin{tabular}{lr}
\hline Uraian & Nilai \\
\hline Jumlah Produksi (Kg) & \\
MT I & $1.605,50$ \\
MT II & 549,00 \\
Total Produksi & $2.151,50$ \\
Harga (Rp/Kg) & \\
MT I & $4.529,00$ \\
MT II & $4.798,00$ \\
Penerimaan (Rp) & \\
MT I & $7.271 .310,00$ \\
MT II & $2.634 .102,00$ \\
Total Penerimaan & $9.905 .412,00$ \\
Total Biaya (Rp) & $3.936 .072,00$ \\
Pendapatan (Rp) & $5.969 .340,00$ \\
Efisiensi & 2,51 \\
\hline
\end{tabular}

Sumber : Analisis Data Primer, 2017

Berdasarkan perhitungan penerimaan dan biaya, dapat diketahui efisiensi usahatani dilihat dari nilai $\mathrm{R} / \mathrm{C}$. Dengan nilai penerimaan sebesar $\mathrm{Rp}$ 9.905.412,00 dan total biaya sebesar Rp 3.936.072,00 maka diperoleh nilai R/C 
sebesar 2,52. Nilai ini menunjukkan bahwa ketika petani mengeluarkan biaya sebesar Rp 1,00 maka akan diperoleh penerimaan sebesar Rp 2,52. Nilai R/C yang lebih besar dari 1 (satu) menunjukkan bahwa usahatani jagung pada lahan kering di Kabupaten Wonosobo efisien. Hal ini sejalan dengan hasil penelitian Lalu (2017) dan Tahir \& Suddin (2017) yang menyimpulkan bahwa usahatani jagung di lahan sawah dan lahan kering terbukti layak diusahakan yang ditunjukkan oleh nilai $\mathrm{RC}>1$.

\section{Alternatif Strategi Pengembangan Usahatani Jagung pada Lahan Kering di Kabupaten Wonosobo}

Focus Group Discussion (FGD) yang dilakukan dengan stakeholder menghasilkan faktor-faktor strategis internal yang mencakup kekuatan dan kelemahan dan faktor-faktor strategis eksternal yang mencakup peluang dan ancaman. Analisis SWOT yang dilakukan berdasarkan faktor-faktor internal dan ekternal menghasilkan enam alternatif strategi pengembangan usahatani jagung lahan kering di Kabupaten Wonosobo sebagaimana tercantum pada Tabel 3.

Secara terperinci, setiap alternatif strategi yang dirumuskan dapat diuraikan sebagai berikut:

\section{Strategi S-O}

Strategi S-O adalah strategi untuk menggunakan kekuatan dalam rangka memanfaatkan peluang. Strategi S-O terdiri atas dua strategi yaitu (1)Peningkatan kuantitas dan kualitas komoditas jagung dengan memanfaatkan secara optimal dukungan kebijakan pemerintah dan (2) Peningkatan produksi jagung melalui perluasan lahan penanaman jagung.

Strategi pertama dapat dilakukan karena usahatani jagung pada lahan kering di Kabupaten Wonosobo memiliki kekuatan berupa ketersediaan lahan, jumlah petani yang banyak, dan petani sudah berpengalaman dalam usahatani jagung. Di sisi lain, pemerintah melalui instansi atau dinas teknis terkait juga berupaya untuk mengembangkan komoditas jagung melalui program PAJALE. Program yang dilakukan pemerintah antara lain bantuan benih dan saprodi, pengadaan alat mesin pertanian, serta optimalisasi lahan dengan penanaman jagung. Kebijakan pemerintah ini merupakan peluang untuk meningkatkan kuantitas dan kualitas komoditas jagung. Melalui program pemberian bantuan benih, saprodi dan mesin pertanian, diharapkan dapat menekan biaya produksi yang dikeluarkan dan kecukupan saprodi dalam usahatanijuga akan meningkatkan produktifitas dan kualitasnya. Penelitian Memon et. al. (2016) menunjukkan bahwa peningkatan penggunaan pupuk, pestisida, benih yang berkualitas, dan perbaikan irigasi dapat meningkatkan produksi jagung di Distrik Mirpurkhas, Sindh. Setiani (2015) menyatakan bahwa simulasi kebijakan 
peningkatan subsidi harga pupuk sebesar $25 \%$ mampu menurunkan biaya produksi padi (3.695\%) dan jagung (2.076\%) sehingga meningkatkan keuntungan total usahatani sebesar $2,39 \%$.

Tabel 3. Matrik SWOT Alternatif Strategi Pengembangan Usahatani Jagung pada Lahan Kering di Kabupaten Wonosobo

\begin{tabular}{|c|c|c|}
\hline EKSTERNAL & $\begin{array}{l}\text { STRENGTH }(S) \\
\text { 1.Lahan kering tersedia } \\
\text { 2.Jumlah petani jagung } \\
\text { banyak } \\
\text { 3.Petani berpengalaman } \\
\text { dalam usahatani jagung } \\
\text { 4.Memiliki kearifan lokal } \\
\text { dalam budidaya dan } \\
\text { pasca panen jagung. }\end{array}$ & $\begin{array}{l}\text { WEAKNESS }(\mathrm{W}) \\
\text { 1.Usahatani jagung } \\
\text { sebagai usaha } \\
\text { sampingan } \\
\text { 2.Modal terbatas } \\
\text { 3.Pemasaran tergantung } \\
\text { pada tengkulak } \\
\text { 4.Kelompok tani belum } \\
\text { berperan optimal } \\
\text { dalam pemasaran }\end{array}$ \\
\hline $\begin{array}{l}\text { OPPURTINITIES }(\mathrm{O}) \\
\text { 1. } \text { Permintaan pasar } \\
\text { tinggi } \\
\text { 2. Adanya kebijakan } \\
\text { PAJALE } \\
\text { 3. } \text { Berkembang industri } \\
\text { pengolahan jagung } \\
\text { 4. } \text { Berkembang } \\
\text { teknologi informasi }\end{array}$ & 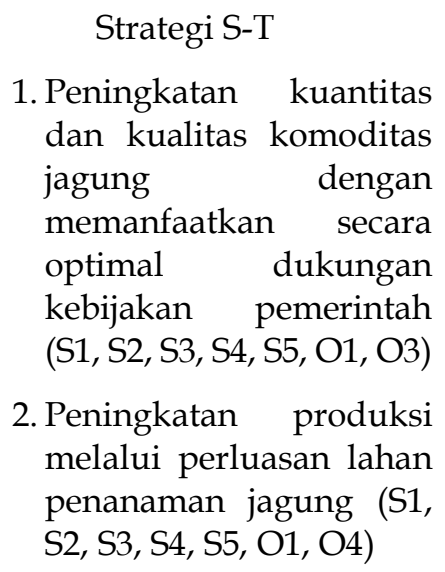 & $\begin{array}{l}\text { Strategi W-O } \\
\text { 1. Perluasan pemasaran } \\
\text { jagung (W3, W4,O1, } \\
\text { O3,O4) } \\
\text { 2. Peningkatan modal } \\
\text { petani }(\mathrm{W} 2, \mathrm{O} 1, \mathrm{O} 2)\end{array}$ \\
\hline $\begin{array}{l}\text { THREATS }(\mathrm{T}) \\
\text { 1. Serangan hama dan } \\
\text { penyakit } \\
\text { 2. Adanya jagung impor } \\
\text { 3. Persaingan dengan } \\
\text { komoditas lain } \\
\text { 4. Harga benih mahal } \\
\text { 5. Harga jagung rendah } \\
\text { 6. Iklim (kemarau } \\
\text { panjang) }\end{array}$ & $\begin{array}{l}\text { Strategi S-T } \\
\text { Pengembangan benih } \\
\text { spesifik lokasi ( tahan } \\
\text { hama dan kekeringan ) } \\
(\mathrm{S} 1, \mathrm{~S} 2, \mathrm{~S} 3, \mathrm{~S} 5, \mathrm{~T} 2, \mathrm{~T} 4)\end{array}$ & $\begin{array}{l}\text { Strategi W-T } \\
\text { Peningkatan peran } \\
\text { kelompok tani dalam } \\
\text { menghadapi persaingan } \\
(\mathrm{S} 2, \mathrm{~S} 3, \mathrm{~S} 5, \mathrm{~T} 2, \mathrm{~T} 3, \mathrm{~T} 4)\end{array}$ \\
\hline
\end{tabular}

Sumber: Analisis Data Primer, 2018 
Strategi peningkatan produksi melalui perluasan lahan dapat dilakukan karena didukung oleh kekuatan berupa banyaknya petani jagung dan pengalaman yang dimiliki sehingga masih memungkinkan upaya peningkatan produksi melalui perluasan lahan. Salah satu peluang yang dapat digunakan untuk memperluas lahan penanaman jagung adalah pemanfaatan lahan hutan. Perhutani Jawa Tengah memberikan kesempatan kepada petani untuk memanfaatkan lahan perhutani untuk menanam jagung. Hal ini merupakan peluang yang dapat dimanfaatkan petani untuk meningkatkan produksi jagung. Hasil penelitian Ratri, dkk (2018) menunjukkan bahwa luas lahan merupakan faktor yang paling berpengaruh dalam penawaran jagung di Kabupaten Wonogiri. Rekomendasi dari penelitian Suartana et al (2016) adalah petani disarankan untuk berupaya menambah luas areal menjadi tiga atau empat hektar agar produktivitas jagung lebih meningkat dua atau tiga kali lipat dari sebelumnya sehingga pendapatan juga biasa meningkat.

\section{Strategi $\mathrm{W}-\mathrm{O}$}

Strategi W-O adalah strategi untuk memanfaatkan peluang dalam rangka mengatasi kelemahan. Strategi W-O terdiri atas dua strategi yaitu (1) Perluasan pemasaran jagung dan (2) Peningkatan modal petani.

Strategi perluasan pemasaran jagung dilakukan karena memperluas jaringan pemasaran merupakan salah satu upaya penting untuk mengembangkan usahatani jagung. Luasnya pasar akan mendorong petani untuk mengembangkan usahatani jagung dalam rangka memenuhi permintaan pasar. Perluasan jaringan pemasaran dapat dilakukan dengan meningkatkan peran kelompok tani dalam pemasaran. Pemasaran secara berkelompok memungkinkan untuk memasarkan jagung melalui kerja sama kelompok tani dengan pengusaha olahan jagung seperti pabrik pakan ternak maupun olahan jagung yang lain. Selama ini petani lebih banyak menjual secara sendiri-sendiri dan tergantung kepada tengkulak sehingga harga yang diterima rendah. Penjualan secara sendiri-sendiri juga menjadi kendala untuk melakukan kerjasama pemasaran dengan pengolah jagung karena ketidakmampuan petani menyediakan jagung dalan kuantitas dan kualitas sesuai permintaan industry pengolah jagung. Pemasaran secara berkelompok juga akan memudahkan mendapatkan informasi pasar sehingga jangkauan pemasaran akan semakin luas. Oleh karena itu pemberdayaan kelompok tani dalam pemasaran jagung penting untuk dilakukan dalam rangka meningkatkan efisiensi dan daya saing komoditas jagung. Selain itu, berkembangnya teknologi informasi juga dapat dimanfaatkan oleh petani dan kelompok tani untuk menambah informasi tentang harga dan permintaan jagung. Teknologi informasi juga dapat dimanfaatkan untuk media pemasaran dengan jangkauan yang lebih luas dan lebih cepat. 
Sedangkan strategi peningkatan modal petani dilakukan karena salah satu kelemahan dalam pengembangan usahatani jagung lahan kering di Kabupaten Wonosobo adalah kurangnya modal yang dimiliki petani. Kelemahan ini dapat diatasi dengan memanfaatkan kebijakan pemerintah untuk meningkatkan modal petani. Kebijakan bantuan modal dari pemerintah seperti Kredit Ketahanan Pangan, Kredit Usaha Rakyat, bantuan modal melalui PUAP (Pengembangan Usaha Agribisnis Pedesaan) dan lain-lain dapat dimanfaatkan oleh petani untuk meningkatkan modal petani. Modal yang memadai memungkinkan petani mengembangkan usahataninya. Peningkatan modal memungkinkan petani membeli sarana produksi dengan cukup dan mengelola usahataninya secara optimal sehingga produksi dan pendapatannya meningkat.. Hasil penelitian Manjorang dan Sagala (2015) menunjukkan bahwa modal berpengatuh positif terhadap pendapatan petanijagung di Desa Tupak Raja Kecamatan Gunung Sitember Kabupaten Dairi.

\section{Strategi S-T}

Strategi S-T adalah startegi untuk memanfaatkan kekuatan dalam menghadapi ancaman. Alternatif strategi yang dirumuskan adalah Pengembangan benih spesifik lokasi (tahan hama dan kekeringan).

Benih merupakan faktor penting dalam usahatani jagung. Hanya saja mahalnya harga benih menjadi ancaman bagi usahatani jagung. Di sisi lain, kekuatan yang dimiliki dalam usahatani jagung adalah pengalaman berusahatani jagung yang dimiliki petani. Oleh karena itu untuk mengatasi mahalnya harga benih dan kesesuaian benih dengan lokasi, dapat dilakukan pengembangan benih oleh petani sendiri. Di beberapa daerah petani sudah ada yang mengembangkan benih sesuai dengan kebutuhannya. Teknik budidaya yang benar serta penggunaan benih unggul yang tahan hama dan kekeringan akan mampu meningkatkan kuantitas dan kualitas jagung yang dihasilkan. Penelitian Palobo dkk (2019) menunjukkan bahwa penggunaan benih hibrida yang berbeda pada usahatani jagung lahan kering di Merauke, Papua menghasilkan produktivitas, pendapatan, dan efisiensi usahatani yang berbeda.

\section{Strategi $W-T$}

Strategi W-T adalah startegi untuk menghadapi ancaman dengan memperkecil kelemahan. Alternatif strategi yang dirumuskan adalah peningkatan peran kelompok tani dalam menghadapi persaingan. Salah satu ancaman dalam pengembangan usahatani jagung pada lahan kering di Kabupaten Wonosobo adalah adanya persaingan baik dengan jagung impor maupun dengan komoditas lain. Adanya jagung impor menyebabkan harga jual jagung local rendah. Hal tersebut mengakibatkan petani mengalami kerugian karena penerimaan rendah sedangkan biaya tinggi. Pada akhirnya petani akan beralih menanam komoditas lain yang lebih menguntungkan dan persaingan dengan 
komoditas lain ini juga menjadi ancaman keberlanjutan usahatani jagung. Upaya yang dapat dilakukan adalah dengan meningkatkan peran kelompok tani dalam memasarkan jagung secara berkelompok sehingga petani memiliki posisi yang kuat di pasar. Selain itu kelompok tani juga dapat ditingkatkan perannya untuk memotivasi petani untuk menanam jagung sehingga tidak berpindah ke komoditas lain.

\section{Simpulan}

\section{SIMPULAN DAN SARAN}

Hasil penelitian menunjukkan bahwa usahatani jagung pada lahan kering di Kabupaten Wonosobo dikakukan dengan rata-rata luas lahan 0,45 ha dan selama MT I dan MT II mengeluarkan biaya sebesar Rp 3.936.072,00, memperoreh penerimaan sebesar Rp 9.905.412,00, sehingga pendapatan sebesar Rp 5.969.340,00. Nilai R/C sebesar 2,51 menunjukkan bahwa usahatani jagung di Kabupaten Wonosobo efisien.

Alternatif strategi pengembangan usahatani jagung pada lahan kering di Kabupaten Wonosobo yang dirumuskan adalah (1) Peningkatan kuantitas dan kualitas komoditas jagung dengan memanfaatkan secara optimal dukungan kebijakan pemerintah , (2) Peningkatan produksi melalui perluasan lahan penanaman jagung, (3) Perluasan pemasaran jagung, (4) Peningkatan modal petani, (5) Pengembangan benih spesifik lokasi ( tahan hama dan kekeringan ), dan (6) Peningkatan peran kelompok tani dalam menghadapi persaingan.

\section{Saran}

Usahatani jagung pada lahan kering di Kabupaten Wonosobo memberikan pendapatan dan sudah efisien sehingga layak dikembangkan. Alternatif strategi yang telah dirumuskan pada penelitian ini sabaiknya dimanfaatkan sebagai informasi dan bahan pertimbangan untuk membuat kebijakan pengembangan jagung pada lahan kering oleh petani maupun pemerintah Kabupaten Wonosobo.

\section{DAFTAR PUSTAKA}

Badan Pusat Statistik Jawa Tengah. 2016. Provinsi Jawa Tengah dalam Angka tahun 2016. Badan Pusat Statistik Jawa Tengah, Semarang. . 2018. Provinsi Jawa Tengah dalam Angka tahun 2018. Badan Pusat Statistik Jawa Tengah, Semarang. . 2019. Provinsi Jawa Tengah dalam Angka tahun 2019. Badan Pusat Statistik Jawa Tengah, Semarang 
Lalu, M. S. 2017. Faktor-Faktor yang Mempengaruhi Usahatani Jagung di Lahan Sawah dan Lahan Kering. Jurnal Pengkajian dan Pengembangan Teknologi Pertanian.20(1):81-90.

Manjorang, S.J.dan E. Sagala. 2015. Pengaruh Faktor-faktor Produksi terhadap Pendapatan Petani Jagung di Desa Tupak Raja Kecamatan Gunung Sitember Kabupaten Dairi. Jurna PLANS Volume 10 No.2. September 2015, halaman 9-20.

Memon, I. N, S. Noonari, H. Wagan, M. H. Lakhio \& A. Wakeel. 2016. Analysis on Technical Efficiency of Hybrid Maize Production in District Mirpurkhas, Sindh. Management and Organizational Studies. 3(2).

Mewalili1, F. Dan R. Abd. Rauf. 2014. Analisis Efisiensi Penggunaan Faktor Produksi Usahatani Jagung Di Desa Bulupountu Jaya Kecamatan Sigi Biromaru Agrotekbis. 2(5): 526-532.

Palobo, F., H. Masbaitubun, dan S. Tirajoh. 2019. Analisis Kelayakan Usahatani Jagung Hibrida Pada Lahan Kering Di Merauke, Papua. Jurnal Sepa. 16 (1): $1-10$.

Rukmana, R. 1995. Teknik Pengelolaan Lahan Berbukit dan Kritis.Yogyakarta: Kanisius

Setiani, 2015 . Produksi Jagung dalam Ekonomi Rumah Tangga Petani Lahan Sawah : Model Simulasi Kebijakan (Studi kasus di Desa Kepuh kembeng Kecamatan Peterongan Kabupaten Jombang). Media Trens Vol. 10 No 2 Oktober 2015. Hal 104-115 Universitas Trunojoyo . Madura .

Setiawan, I. 2007. Alternatif Pemberdayaan Bagi Peningkatan Kesejahteraan Petani Lahan Kering. http://pustaka.unpad.ac.id/archives/28827/ . Diakses Tanggal 2 Desember 2010.

Suartana,I.W., M.Antara, dan Damayanti. 2016. Strategi Pengembangan

Usahatani Jagung Di Desa Malik Trans Kecamatan Bualemo Kabupaten Banggai. J. Agroland 23 (3) : 190 - 197, Desember 2016. Halaman 190-197.

Suratiyah, K. 2015. Ilmu Usahatani. Penebar Swadaya, Jakarta.

Tahir, A.G. dan A.F.Suddin. 2017. Analisis PendapatanUsahatani Jagung pada Lahan Sawah dan Tegalan di Kecamatan Ulaweng,Kabupaten Bone Sulawesi Selatan. Jurnal Galung Tropika, 6 (1) April 2017, halaman 1-11.

Rangkuti. F. 2001. Analisis Swot Teknik Membedah Kasus Bisnis. Gramedia Pustaka Utama. Jakarta

Ratri, D. R., W. Rahayu, and E. Antriyandarti. 2018. Determinants of Maize Supply from Dryland Farming: Evidence from Central Java. Asian Journal of Scientific Research. 12(1): 79-83. 